\title{
BENDA ASTRONOMI DALAM AL-QURAN DARI PERSPEKTIF SAINS
}

\author{
Muhammad Hasan \\ Sekolah Tinggi Agama Islam Negeri (STAIN) Pontianak \\ Jl Letnan Jendral Soeprapto No 19 Pontianak 78121 \\ e-mail: hasaniain@yahoo.co.id
}

\begin{abstract}
The objects in the sky in an astronomical perspective is very much the type and amount, but in the perspective of The Quran consists only of the sun, moon, and stars. The Quran gives cues and clues about the movement of the heavenly bodies. Sky objects in the perspective of the Koran already set his destiny, and had been subdued, so consistently and definitely outstanding. According to The Quran cue each celestial bodies, circulation and no silent, including the sun are also outstanding. In the circulation of the month, has its own characteristics, because only months in circulation set manzilah-manzilah, so the moon when seen from Earth show different form, sometimes the perfect (full moon), and sometimes show an imperfect form. Thus, it can be well known, when the month of the date of 1,2,3, and so on, so that people can practice their religion is based on the moon trip.
\end{abstract}

\begin{abstract}
Abstrak: Benda-benda di langit dalam perspektif astronomi sangat banyak jenis dan jumlahnya, namun dalam perspektif al-Quran hanya terdiri dari matahari, bulan, dan bintang. Al-Quran memberikan isyarat dan petunjuk mengenai pergerakan benda-benda langit tersebut. Benda-benda langit dalam perspektif al-Quran sudah ditetapkan takdir-Nya, dan telah ditundukkan, sehingga beredar secara konsisten dan pasti. Menurut isyarat al-Quran masing-masing benda langit, beredar dan tidak ada yang diam, termasuk matahari juga beredar. Dalam peredaran bulan, memiliki ciri tersendiri, karena hanya bulan yang dalam peredarannya ditetapkan manzilah-manzilah, sehingga bulan ketika dilihat dari bumi menunjukkan wujud yang berbedabeda, kadang sempurna (bulan purnama), dan terkadang menunjukkan wujud yang tidak sempurna. Dengan demikian, dapat dikenal dengan baik, kapan bulan tanggal 1,2,3, dan seterusnya, sehingga manusia dapat melaksanakan ibadah berdasarkan perjalanan bulan tersebut.
\end{abstract}

Keywords: matahari, bulan, bintang, al-Quran, astronomi 


\section{A. Pendahuluan}

Benda luar angkasa dalam perspektif al-Quran meliputi tiga hal ${ }^{1}$ : matahari ${ }^{2}$, bulan ${ }^{3}$, dan bin-tang. ${ }^{4} \mathrm{Al}-$ Quran mengulang tiga istilah tersebut dengan berbagai redaksi dan istilah yang berbeda sebanyak $84 \mathrm{kali}$. Dalam kajian astronomi semua benda ruang angkasa termasuk bumi berputar mengelilingi matahari.

Matahari merupakan pusat benda langit yang memancarkan sinar sendiri. Sedangkan, bulan memantulkan cahaya karena menerima sinar matahari, sementara bintang adalah benda langit yang memiliki cahaya sendiri. Bagaimana dengan perspektif al-Quran? Apakah menurut al-Quran juga demikian?.

Persoalan benda-benda langit dan peredarannya, merupakan persoalan yang menarik. Dikatakan demikian, karena persoalan tersebut merupakan

\footnotetext{
${ }^{1} \mathrm{QS}$ al-Hajj [22]: 18.

2Matahari dalam al-Quran dibahasakan dengan kata syams شمس dan kadang-kadang dibahasakan dengan kata sirājj/ سراج

${ }^{3}$ Bulan dalam al Quran dibahasakan dengan kata syahr شهر قمر , qamar hilāl هلال. Masing-masing kata ini dalam al-Quran digunakan untuk maksud yang berbeda-beda. Kata syahr شهر berorientasi pada makna bulan yang menunjukan arti waktu atau perhitungan waktu, misalnya dalam QS. al-Baqarah [2]: 185,194,197,217,226, dan 234. QS. al-Nisa' [4] :92. QS. al-Mā'idah [5]: 97. QS. al-Taubah [9]: 2, 36, QS. al-Ahquaf [46]: 15, QS al-Mujādalah [58]: 4, QS. al-Ṭalaq [65]: 4. Semua ayat tersebut menggunakan kata syahr untuk perhitungan waktu. Kata syahr شهر dalam al-Quran diulang sebanyak 13 kali dan menun-jukkan makna yang sama yakni bulan dalam arti perhitungan waktu dan bukan menunjuk-kan makna bulan dalam arti hakiki benda, sedangkan yang menunjukkan makna hakiki adalah kata qamar قر هلال dan hilāl.

${ }^{4}$ Bintang dalam al-Quran dibahasakan dengan kata nujüm نجوم كوكب daukab كوك dan burūj بروج.
}

salah satu pondasi untuk memahami per-soalan hisab rukyat secara sahih. Peredaran matahari berkaitan langsung dengan penentuan arah kiblat dan penentuan ibadah salat. Perdebatan mengenai waktu subuh yang belum tuntas pada hakekatnya merupakan perdebatan mengenai pergerakan matahari. Perdebatan seputar penentu-an awal bulan hijriah, perbedaan dalam mengawali puasa, perbedaan penentuan idul fitri dan idul adha, merupakan implikasi dari pemahaman terhadap teks syar'i. Oleh karena itu, pemahaman yang komprehensif terhadap ayatayat yang berkaitan dengan peredaran matahari, bulan, dan bintang sangat diperlukan.

Matahari dan bulan merupa-kan obyek dalam perhitungan ka-lender masehi (solar) dan kalender hijriah (luni), sementara benda-benda langit yang berkaitan dengan bintang, berpotensi mengganggu dalam pelaksanaan rukyat.

Artikel ini akan mengkaji ayatayat yang berkaitan dengan peredaran benda-benda langit secara tematik. Karena itu, hal penting dalam makalah ini adalah pembatasan dan pemaknaan isti-lah benda langit yang terdapat dalam al-Quran dilihat dari perspektif al-Quran, dan perspektif kebahasaan. Selanjutnya, akan di-paparkan bendabenda langit yang terdapat dalam alQuran dilihat dari perspektif al-Quran, terutama yang berkaitan dengan ciri dan karakteristiknya. Setelah mengetahui karakteristiknya akan dideskripsikan, peredaran benda-benda langit dilihat dari perspektif al-Quran, perspektif mufassir, dan perspektif astronom. 
Pendekatan yang digunakan untuk menjawab persoalan di atas menggunakan pendekatan tafsir maudū'ì. Adapun langkah-langkah yang dilakukan adalah: 1) menginventarisasi ayat-ayat yang berkaitan dengan astronomi. 2) Mengelompokkan ayatayat ter-sebut berdasarkan bahasa yang digunakan. 3) Mengelompokkan ayat-ayat tersebut berdasarkan tempat dan waktu turunnya. 4) Mencari $a s b \bar{a} b$ al-Nuzūl yang ber-kaitan dengan ayat tersebut. 5) Mencari penjelasan katakata yang dianggap urgen dalam kamus. 6) Melihat pendapat ulama tafsir mengenai ayat tersebut dan membandingkan dengan pendapat ahli astronomi. 7) Menarik kesimpulan akhir dari ayat/beberapa ayat tersebut.

\section{B. Matahari}

Al-Quran menyebut istilah matahari dengan kata شمس dan سراج . AlQuran mengulang kata matahari (شمسج) sebanyak 32 kali, dan menggunakan kata matahari (sirāj/سراج) sebanyak empat kali, yakni dalam QS. al-Furqān [25]: 61, al-Ahzab (33):46, Nūḥ [71]:16, al-Naba [78]: 13. Matahari (شمس) disebut secara bersamaan dengan kata qamar (قمر) dan nujūm (نجوم) sebanyak satu kali yakni dalam QS. alḤajj [22]: 18 sebagai berikut:

$$
\begin{aligned}
& \text { أَلََْ تَرَ أَنَّ اللَّهَ يَسْجُحُ لَهُ مَنْ فِي السَّمَوَاتِ وَمَنْ فِي }
\end{aligned}
$$

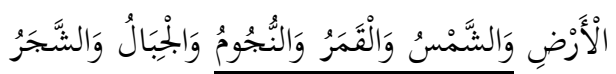

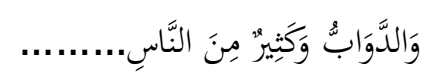

Apakah kamu tiada mengetahui, bahwa kepada Allah bersujud apa yang ada di langit, di bumi, matahari, bulan, bintang, gu-nung, pohonpohonan, bina-tang-binatang yang melata dan sebagian besar daripada manusia.....

Ayat ini menggambarkan ketaatan ciptaan Allah kepada penciptanya. Jadi kata matahari (شمس), kata qamar (قمر) dan nu-jūm (نجوم) disebutkan secara bersamaan untuk menunjukkan ketaatan ciptaan-Nya. Dalam konteks ini Allah menggambarkan benda-benda ciptaan-Nya sebagai makhluk yang tak pernah durhaka kepadanya, dan semuanya tunduk kepada perintah-Nya kecuali manusia. Ayat ini mem-berikan indikasi bahwa matahari (شمس ), qamar (قمر) dan nujūm (نجوم) akan selalu berjalan sesuai dengan perintah Allah. Sebagaimana dikatakan di atas, makhluk ciptaan Allah senantiasa mentaati Allah, maksudnya ketundukan matahari, bulan, dan bintang dalam bentuk selalu mengikuti ketentuan yang telah ditetapkan Allah untuknya.

Matahari (شمس ) secara bersamaan dengan kata qamar (قرى) dan kaukab disebut-kan dalam al-Quran sebanyak 1 kali, yakni dalam QS. Yusuf [12]: 4. Dalam QS. Yusuf (12): 4 matahari (شمس), qamar (قمر) dan kaukab اذف dideskripsikan sebagai berikut:

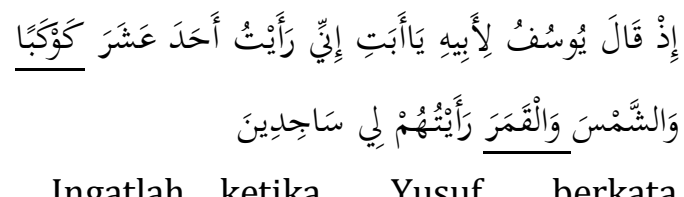
kepada ayahnya: "Wahai ayahku, sesungguhnya aku ber-mimpi melihat sebelas bintang, matahari, dan bulan. Kulihat semuanya sujud kepadaku." Ayat ini menggambarkan kehadiran matahari, bulan, dan bintang dalam mimpi Yusuf dan ketundukannya kepada Yusuf. Karena itu, ayat ini lebih bero-rientasi pada persoalan Yusuf, bukan persoalan astronomi. Pe- 
nggunaan kata bintang, bulan, dan matahari dalam ayat ini hanya sebagai obyek mimpi Yusuf saja, bukan bintang, bulan, dan matahari yang hakiki.

Matahari (شمس) disebut secara bersamaan dengan kata qamar (قمر) sebanyak 17 kali. Penyebutan matahari (شمس) bersamaan dengan kata qamar (قر ) sebanyak 17 kali di temui dalam QS. al-An'ām [6]: 96, QS. al-A'rāf [7]: 54, QS. Yūnus [10]: 5, QS. al-Ra'd [13]: 2, QS. Ibrāhīm [14]: 33, QS. al-Naḥl [16]:12, QS. al-Anbiyā' [21]: 33, QS. al'Ankabūt [29]: 61, QS. Luqmān [31]: 29, QS. Fāṭir (35): 13, QS. Yāsīn (36): 39-40, QS. al-Zumar (39): 5, QS. Fușșilat [41]: 37, QS. al-Raḥmān [55]: 5, QS. Nūḥ [71]: 16, dan QS. al-Qiyāmah (75): 9.

Kumpulan ayat-ayat tersebut, kandungan isinya dapat dikategorikan sebagai berikut: Per-tama, sebanyak sebelas kali menunjukan peredaran matahari dan bulan, yakni pada QS. alAn'ām [6]: 96, QS. al-A'rāf [7]: 54, QS. Yunus [10]: 5, QS. al Ra'd [13]: 2, QS. Ibrahim (14): 33, QS. al-Anbiya' [21]: 33, QS. Lukman [31]: 29, QS. Fāṭir [35]: 13, QS. Yāsīn [36]: 39-40, QS. al-Zumar (39): 5, QS. al-Rahman [55]: 5. Kedua, dua kali menggambarkan manfaat matahari dan bulan bagi kehidupan manusia, yakni QS. al-Nahl [16]:12, QS. Nuh [71]: 16. Ketiga, satu kali mengenai keingkaran orang kafir terhadap penciptaan langit, bumi, ketundukan matahari, dan bulan yakni QS. al-Ankabut [29]: 61. Keempat, satu kali tentang larang-an sujud kepada matahari dan bulan yakni pada QS. Fușșilat [41]: 37. Kelima, satu kali mengenai ciri-ciri kehancuran alam, yakni QS. al-Qiyamah (75): 9.
Matahari sebagai benda luar angkasa digambarkan dalam beberapa ayat antara lain: QS al-Furqan (25): 61, QS Nūh [71]:16, dan QS. alNaba' [78]: 13, menggambarkan matahari sebagai sirāj (سراجا). kata siraj dalam kamus al-Munawwir diartikan pelita atau lampu. De-ngan demikian, matahari meman-carkan sinar. Sedangkan, pada QS.Yunus (10): 5 matahari digambarkan sebagai benda langit yang bersinar. Mengacu kepada ayat-ayat ini dapat disimpulkan bahwa ciri-ciri matahari adalah benda langit yang memiliki sinar, dimana sinarnya sebagai penerang bagi kehidupan.

\section{Bulan}

Bulan dalam al-Quran disebut dengan istilah syahr (شهر), qamar (هر) ), dan hilāl (هلال) diulang sebanyak 40 kali. Sedangkan, bulan dengan istilah qamar (فر (هلال), dan hilāl) secara bergan-dengan diulang sebanyak 27 kali. Bulan dalam istilah qamar (قمر) saja diulang sebanyak 26 kali. Karena syahr (شهر) merupakan kata yang tidak menunjukkan pada pengertian bulan yang hakiki maka tidak akan dibahas dalam makalah ini secara mendalam. Namun demikian, kata (شهر ) memiliki keterikatan dengan qamar dan hilāl, karena kata ini sebagai perhitungan jumlah bilangan qamar dan hilāl.

Kata qamar (همر) dan hilāl (هلال) bermakna bulan dalam arti hakiki. Keduanya menyatakan makna bulan dalam arti hakiki, namun memiliki perbedaan maksud. Kata qamar (قمر) bermakna bulan yang sempurna. Ini dapat dipahami dari QS. al-Insyiqah [84]: 18 (dan dengan bulan apabila 


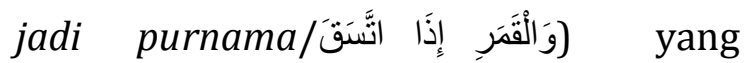
menghubungkan kata qomar dengan purnama. Begitu juga ketika al-Quran selalu mengungkapkan kata qamar (قمر) dalam bentuk mufrad, melambangkan bahwa bulan yang sempurna (قمر) hanya sekali setiap bulan (شهر), yaitu pada bulan purnama. Dengan demikian, kata qamar (قمر) hanya berarti bulan purnama (ketika penampakan bulan sempurna).

Kata hilāl (هلال) diungkapkan dalam al-Quran hanya satu kali dalam bentuk jamak (هلة). Kata ini ditemui pada QS. al-Baqarah (2): 189. Ini dapat dipahami bahwa hilāl itu berulangulang, tidak hanya seka-li. Dalam arti, perjalanan bulan dari sangat tipis menuju sempur-na dan dari sempurna menuju tipis kembali dapat disebut hilāl. $^{5}$ Dengan demikian, peredaran bulan ( قدر dan هلال ) selama satu bulan (شهر) terdiri dari, sekali bulan "qamar" dan yang lainnya adalah bulan "hilāl". Ini berarti bahwa "hilāl" bermakna bulan yang tidak sempurna, nampak sedikit, sebagian, separuh, atau hampir sempurna, ketika sempur-na maka tidak disebut hilāl, tetapi disebut qamar. Dengan kata lain penampakan qamar yang tidak sempurna disebut hilāl, sedangkan kata qamar itu sendiri lebih berorientasi pada hakikat bulan yang sempurna.

Berdasarkan pada QS. Nuh [71]: 16 dan QS. Yunus [10]: 5, sebagaimana diungkapkan pada bagian terdahulu dapat disimpul-kan bahwa bulan

5Pemaknaan kata hilal yang demikian, berbeda dengan pemaknaan hilal dalam pandangan astronomi, dimana secara astronomi hilāl diartikan penampakan bulan yang halus seperti benang yang tampak pada awal bulan. merupakan benda langit yang memiliki cahaya (نور). Mengingat sebagian besar ayat-ayat tentang matahari dan bulan selalu digandeng, maka dapat disimpulkan bahwa antara sinar matahari dan cahaya bulan memiliki keterikatan. Ini membe-rikan indikasi bahwa cahaya bulan sangat tergantung pada sinar matahari. Kesimpulan ini diperkuat oleh pendapat Za-makhsyari yang menyatakan bah-wa: “6 الضياء أقوى من النور".

\section{Bintang}

Bintang disebut al-Quran dengan istilah بروج , dan dan Al-Quran tidak banyak menceritakan bintang, baik de-ngan istilah nujūm (نجوم) dan buruj (بروج) maupun dengan istilah kaukab (كوكب). Ketiga Isti-lah tersebut digunakan secara bergantian untuk menggambarkan obyek yang berbeda. Misalnya, dalam QS. al-An'am (6): 76 digunakan kata kaukab (كوكب), disini kata kaukab (كوكب) digunakan untuk menggambarkan bintang sebagai benda yang di-kagumi Ibrahim, kemudian dalam QS. Yusuf (12): 4 kata kaukab (كوكب) digunakan untuk meng-gambarkan bintang dalam alam mimpi, sementara dalam QS. al-Nur [24]: 35, kata kaukab (كوكب) digunakan untuk menggambarkan bintang sebagai benda langit yang memiliki cahaya, namun sebagai obyek perumpamaan. Dari sini dapat dipahami bahwa kata kaukab (كوكب) dalam al-Quran digunakan untuk menggambarkan bintang sebagai benda langit yang berada dalam alam khaya-lan/angan-angan atau sesuatu tt, h. 494 .
${ }^{6}$ Zamakhzari, Tafsir al Kassyaf, juz 2, tp: 
yang berada dalam dunia ide. Jadi kata kaukab (كوكب), bukan untuk menunjukkan bintang yang ada dalam dunia realitas, tetapi menunjuk pada bintang yang ada dalam ide.

QS. al-Hajj [22]:18 mengguna-kan kata nujūm (نجوم), untuk menggambarkan bintang sebagai benda langit yang tunduk pada perintah Allah. Dalam QS. al-Najm [53]: 1 kata nujūm (نجوم), diguna-kan untuk menggambarkan bin-tang sebagai benda langit untuk obyek sumpah (qasam). Dalam QS. al-Tariq [86]: 3 kata nujūm (نجوم), digunakan untuk meng-gambarkan bintang sebagai benda langit yang bercahaya. Berdasar-kan pada beberapa ayat di atas kata nujūm (نجوم), memiliki makna bintang dalam arti yang hakiki. Pernyataan ini diperkuat oleh QS. atTakwir [81]: 2 yang meng-gambarkan ciri hari kiamat dengan berjatuhannya bintang (نجوم). Di sini digunakan kata nujūm (نجوم), bukan kaukab. Oleh karena itu, tampaknya pengguna-an kata nujūm dalam al-Quran untuk menggambarkan bintang dalam pengertian yang hakiki. Sehingga, ilmu yang berbicara me-ngenai perbintangan, disebut ilmu nujūm.

Selain kata nujūm (نجوم), untuk menggambarkan bintang, dalam alQuran digunakan kata burūj (بروج) sebagaimana ditemui dalam al-Hijr (15): 16, al-Furqan (25):61, QS. al-Burūj (85):1. Dalam Tafsir al-Ṭabarī diceritakan bahwa menurut Ibn Abbas yang dimaksud dengan burūj adalah: "qusur fi samā'i” yakni gugusan bintang- bintang. ${ }^{7}$ Berdasarkan pada QS. an-Nur (24): 35, dan QS. al-Ṭariq (86): 3 memberikan pe-mahaman bahwa bintang adalah benda langit yang memancarkan cahaya. Sedangkan, QS. al-Buruj (85): 1, menggambarkan gugusan bintang di langit. Kata burūj dalam ayat tersebut meng-gambarkan ciri-ciri dari nujūm. Karena itu, bintang memiliki ciri-ciri diantaranya adalah benda langit yang membentuk gugusan. Gugusan bintang di langit diper-kuat oleh QS. al-An'am [6]: 97. Menurut Shihab bintang merupa-kan petunjuk perjalanan manu-sia, baik di darat maupun di laut. Dengan mengetahui bintang, terutama bintang tak bergerak, seseorang yang akan bepergian dapat menentukan arah yang hendak dituju. ${ }^{8}$

\section{E. Peredaran Matahari dan \\ Bulan.}

Pada bagian terdahulu telah diuraikan bahwa benda-benda la-ngit dalam perspektif al-Qur an terdiri dari matahari ${ }^{9}$ (syams), bulan ${ }^{10}$ (qamar dan hilāl), dan bintang (nujūm). Peredaran ben-da-benda tersebut ditemukan da-

${ }^{7}$ Al-Tabari, Muhammad bin Jarīr bin Yazid bin Kaśir bin Gālib al-Amlī 224-310 H, Jāmi' al-Bayān fì Ta'wīl al-Qurān, juz 24, tahqiq Ahmad Muhammad Syākir, Beirut: Muassah arRisalah, 2000 M/1420 H, h. 331.

${ }^{8}$ Quraish Shihab, Tafsir al-Misbah, Volume 4, Jakarta;Lentera Hati, 2006 , 211.

${ }^{9}$ Dalam ilmu Astronomi matahari disebut dengan bintang yang paling dekat dengan kita, yang memiliki dan memancarkan cahaya sendiri Modji Raharto et.al. Islam untuk Disiplin Ilmu Astronomi, Jakarta:Dirjen Bagais, 2002 h. 21.

10Secara astronomi bulan merupakan benda langit yang paling dekat dengan bumi dan merupakan satelit alam bumi. Modji Raharto et.al., Islam, h. 20. Namun, dalam perspektif al-Quran matahari tidak dikelompokkan dalam istilah bintang. 
lam al-Quran yakni QS. al-An'am [6]: 96, QS. al-A'raf [7]: 54, QS. Yunus [10]: 5, QS. ar Ra'd [13]: 2, QS. Ibrahim [14]: 33, QS. al-Anbiya' [21]: 33, QS. Lukman (31): 29, QS. Fāțir (35): 13, QS. Yāsīn (36): 39-40, QS. al-Zumar (39): 5, QS. arRahman (55): 5. Dalam ayat-ayat ini peredaran matahari dan bulan (قر ) selalu disebutkan secara bersamaan.

Dilihat dari tempat turun-nya, semua ayat yang berbicara mengenai peredaran matahari dan bulan termasuk dalam ke-lompok ayat-ayat makkiyah kecua-li QS. al-Ra'd (13): 2. Ayat ini termasuk kelompok ayat madani-yah. Dengan demikian, ayatayat tersebut, selain QS. al-Ra'd (13): 2 diturunkan sebelum nabi hijrah. Adapun QS. al-Ra'd (13): 2 ditu-runkan setelah Nabi hijrah. Menurut al-Tabarī QS. ar-Ra'd (13):2 mengenai hikmah dicipta-kan langit, menurutnya langit sebagai atap bagi bumi. Karena itu, menurutnya kontruksi langit dan bumi ibarat bangunan yang utuh, yang kemudian di dalam-nya dilengkapi dengan matahari dan bulan. ${ }^{11}$ Menurut al-Sa'di penundukan matahari dan bulan oleh Allah dalam ayat ini untuk kemaslahatan manusia dan ke-maslahatan tumbuh-tumbuhan di bumi. Sementara, yang dimaksud dengan "yajrī liajalim musamma" menurutnya, dengan pengaturan Allah, matahari dan bumi beredar dengan teratur, tidak saling mendahului dan tidak saling tab-rakan sampai pada waktu yang telah ditentukan. ${ }^{12}$

11al-Tabarī, Jāmi' al-Bayān, juz 24, h 249.

${ }^{12}$ As-Sa'di, 'Abdu ar-Rahman bin Nāśir bin as-Sa'di, 2000 M/1420 H, Tafsīr al-Karìm arRahman fì tafsīr Kalām al-Manān, tahqiq 'Abd ar-Rahman bin ma'lā al-wīhaq, jilid 1, Beirut: Muassah ar-Risalah. 412.
Mengacu pada penjelasan di atas, QS. ar-Ra'd (13): 2 dapat dipahami bahwa matahari dan bulan beredar dengan teratur. Dalam peredarannya matahari dan bulan memiliki waktu ma-sing-masing. Bulan memiliki waktu untuk beredar dan sampai pada tempatnya. Matahari juga punya waktu untuk beredar dan sampai pada tempatnya. ${ }^{13}$ Keduanya ber-edar sesuai dengan waktu yang telah ditentukan oleh Allah. Menurut ahli Astronomi, per-edaran bulan mengelilingi bumi selama 27,321661 hari, sedangkan peredaran bumi dan bulan mengelilingi matahari selama 365,256360 hari. ${ }^{14}$

Dilihat dari redaksinya ayat-ayat yang berbicara mengenai peredaran matahari dan bulan tidak terdapat pertentangan an-tara yang makkiyah dan yang madaniyah. Berikut ini sederetan ayat-ayat tentang peredaran ma-tahari dan bulan yang diturunkan sebelum nabi hijrah, yakni: QS. al-An'am (6): 96, QS. al-A'raf (7): 54, QS. Yunus (10):5, QS. Ibrahim (14): 33, QS. alAnbiya' (21): 33, QS. Lukman (31): 29, QS. Fāțir (35): 13, QS. Yāsīn (36):39-40, QS. az-Zumar (39):5, QS. al-Rahman (55): 5. Dari ayat-ayat tersebut ditemui kata kunci (key words) berkaitan dengan peredaran matahari dan bulan. Kata kunci tersebut adalah kata taqdìr.

Kata taqdīr ditemui dalam alQuran hanya tiga kali dan semuanya

13Menurut ahli astronomi peredaran matahari adalah peredaran semu yang diakibatkan oleh gerak rotasi bumi pada sumbunya sebesar $360^{\circ}$ per 24 jam, sehingga seolah-olah matahari bergerak dari Timur ke Barat. Baca, Muhyidin Khazin, Ilmu Falak, Yogyakarta:Buana pustaka, 2004, h.125

${ }^{14}$ Saadoe'ddin Djambek, Hisab Awal Bulan, Jakarta: Tintamas, 1976, 7. 
dalam konteks pem-bicaraan tentang peredaran mata-hari dan bulan, yakni dalam QS. al-An'am (6): 96, QS, Yāsīn (36): 38, dan QS. Fuṣsilat (41): 12. Kata تَقْدِيرُ kan untuk makna pengaturan dan ketentuan yang sangat teliti dalam konteks penciptaan alam semesta. Oleh karena itu, kata ini dalam al-Quran hanya digunakan untuk menunjukkan konsistensi hu-kum-hukum Allah yang ber-laku di alam raya. Menurut Shihab kata takdīr mengandung arti: 1) menjadi-kan sesuatu memiliki kadar serta sistem tertentu dan teliti. 2) menetap-kan kadar sesuatu, baik yang berkaitan dengan materi, maupun waktu. Penggunaan kata takdir diperkuat oleh kata (العزيز) al'Azīz/ Maha Perkasa dan (العليم) al'Alim/ Maha Mengetahui pada akhir ayat bertujuan menjelaskan bah-wa pengaturan Allah terhadap benda langit seperti matahari yang demikian besar, dapat ter-laksana karena Dia Maha Perkasa sehingga semua tunduk kepada-Nya, dan Maha Mengetahui sehingga pengaturan-Nya sangat teliti dan mengagumkan. ${ }^{15}$ De-ngan demikian, peredaran mata-hari dan bulan sudah ditentukan kadar peredarannya, sehingga akan selalu beredar secara kon-sistensi berdasarkan garis edarnya.

QS. al-An'am (6): 96 menyata-kan:

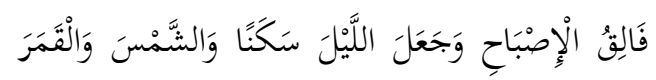

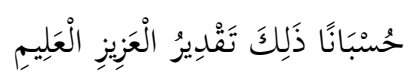

Dia menyingsingkan pagi dan menjadikan malam untuk ber-istirahat, dan (menjadikan) mata-hari dan bulan

${ }^{15}$ Quraish Shihab, Tafsir al-Mishbah, Vol. 13, h. 209 untuk perhitungan. Itulah ketentuan Allah Yang Maha Perkasa lagi Maha mengetahui (al-An'am [6]: 96).

Kata نَقْْيرن dalam ayat di atas menguatkan kata husbānā (حسبانا). Kata Husbānā (حسبانا) secara bahasa terambil dari kata (حسابا) hisābā yang berarti kesempurna-an, sehingga ayat tersebut berarti perhitungan yang sempurna dan teliti. Kemudian hasil perhitungan tersebut ditetapkan sebagai takdir. Berkaitan dengan ketelitian dalam penciptaan perhitungan peredaran benda-benda langit juga disinggung dalam firmanNya yang lain, misalnya dalam QS alRahman [55]: 5. ${ }^{16}$ Mengacu pada dua ayat ini dapat ditarik kesimpulan bahwa peredaran benda-benda langit sedemikian konsisten dan pasti, sehingga tidak mungkin terjadi tabrakan antar benda langit yang satu dengan benda langit yang lainnya. Menurut Shihab, karena peredaran matahari dan bulan sangat konsisten dan pasti, maka dapat dijadikan sebagai alat untuk melakukan perhitungan waktu, tahun, bulan, minggu dan hari bahkan menit dan detik. $^{17}$

Dalam peredaran bulan ditetapkan manzilah-manzilah. Ini ditemui dalam QS.Yunus (10): 5, dan QS Yāsīn (36): 39. Ber-dasarkan kedua ayat ini dapat dipahami bahwa bulan memiliki manzilah-manzilah (fase-fase)

16Menurut Quraish Shihab dalam Tafsir al-Misbah Vol. 13, h. 497 kata حسبا husbān dalam QS. al-Rahman [55]: 5 terambil dari kata hisāb yakni perhitungan. Penambahan huruf alif I dan nun ن pada kata tersebut menurutnya mengandung makna ketelitian dan kesempurnaan.

${ }^{17}$ Quraish Shihab, Tafsir al-Mishbah, Vol. 4, h. 210 . 
dalam peredarannya. Dalam ayat tersebut dikatakan qaddarahu manāzilah. Al-Ṭabari mengatakan bahwa kata manāzilah pada ayat di atas hanya untuk bulan saja, bukan untuk matahari. Dia beragumentasi bahwa perhitung-an syahr dan sinin hanya dapat diketahui dengan qamar. $^{18}$ De-ngan demikian, dapat dipahami bahwa bulan memiliki manzilah-manzilah dalam perjalanannya. Karena bulan memiliki manzilah-manzilah, maka dapat dilihat dari bumi setiap malam dalam bentuk yang berbeda-beda, sehingga ada bulan (hilāl) dan ada bulan (qa-mar). Oleh karena itu, akan melahirkan sistem perhitungan atau penanggalan bulan kamariah.

Isyarat manzilah yang di-miliki oleh bulan diperkuat oleh hasil penelitian yang menyatakan bahwa perjalanan bulan dari bulan mati (muhaq) sampai de-ngan bulan purnama dan menuju bulan mati lagi memiliki fase-fase antara lain: 1). Bulan baru/ bulan mati, 2) Kuartir pertama 3) Bulan purnama 4) Kuartir ketiga, yakni ketika bulan beredar ke arah perempat ke-tiga. ${ }^{19}$ Menurut al-Jailani perubahan penampakan wajah bulan dari bumi sebagai akibat adanya manzilah-manzilah. Dalam hal ini, wajah bulan nampak berbeda dari waktu ke waktu, yang dimulai dengan muhāq (bulan mati) yakni ketika terjadi peristiwa ijtimak antara bulan dan matahari, selanjutnya hilāl (bulan baru) yakni ketika bulan bergerak maka ada bagian bulan yang menerima sinar dari matahari terlihat dari bumi, berikutnya

${ }^{18} \mathrm{Al}$-Ṭabarī, Jāmi', Juz 15, h 23.

${ }^{19}$ Saadoe'ddin Djambek, Hisab, h. 5. tarbi' awwal (kwartir pertama) yakni ketika bulan bergerak semakin jauh dari titik ijtimak, selanjutnya badr (bulan purnama) yakni ketika terjadi peristiwa istiqbal dimana semua permukaan bulan menghadap matahari, kemudian tarbi' akhir (kwartir terakhir) ketika bulan meninggalkan matahari setelah terjadinya peristiwa istiqbal, dan akhirnya kembali pada bentuk muhāq hingga pada proses ijtimak kembali. ${ }^{20}$

Ayat yang berkaitan dengan peredaran bulan yang dijelaskan dalam dalam QS. Yāsīn (36): 39 adalah QS. Yāsīn (36): 37-3821. Menurut Shihab, Ayat 37 meng-ilustrasikan bumi dalam keadaan gelap. Kemudian, Matahari memancarkan sinarnya ke bumi, maka bagian tertentu dari bumi diliputi oleh sinarnya. Sinar matahari itu diilustrasikan dengan kulit dan malam di-ilustrasikan dengan jasmani bina-tang yang tertutup kulit. Lalu sedikit demi sedikit sinar itu diambil dan dikeluarkan bagai-kan binatang yang dikuliti. Setiap saat, berpisah kulit itu dari jasmaninya, setiap itu pula kegelapan muncul, lalu setelah selesai pengulitan yakni setelah posisi matahari meninggalkan bumi karena peredaran kedua-nya, maka kegelapan pun menu-tupi bumi. ${ }^{22}$ Ayat 38 mengandung makna: 1) Matahari bergerak menuju ke tempat

20Zubair Umar al-Jailani, al-Khulāsah alWafiyyah $f$ al-Falak bijadwal al-Lughāritmiyyah, Kudus: Menara Kudus, t.th, 42-43.

21Menurut Shihab kata naslakhu pada سلخُ salakhu yang biasa digunakan dalam arti menguliti binatang, sedangkan yang dimaksud dalam ayat tersebut menurutnya ádalah mengeluarkan.

${ }^{22}$ Shihab, Tafsir al-Mishbah, Vol. 11, h. 540. 
perhentiannya setiap hari. 2) Matahari bergerak terus-menerus sampai waktu yang ditetapkan Allah untuk per-hentian geraknya, yakni pada saat dunia akan kiamat. ${ }^{23}$

Zuhaili menjelaskan bahwa bulan dan matahari tidak mungkin bertemu. Keduanya, menurut Zuhaili memiliki tempat dan kekuasaan. Kekuasaan bulan pada malam hari dan kekuasaan matahari pada siang hari. Karena masing-masing memiliki tempat kekuasaan, maka matahari dan bulan akan selalu beredar pada garis edarnya dan tidak akan saling bertabrakan. $^{24}$ Sadoe'ddin menambahkan bahwa antara kekuasaan bulan dan kekuasaan matahari dibatasi oleh garis ufuk, yang menjadi batas peralihan siang kepada malam. ${ }^{25}$ Sementara, Shihab dengan bertolak dari kata yasbahūn pada QS. Yāsīn (36):40, menjelaskan bahwa ruang angkasa diibaratkan samudera luas, dimana benda-benda langit diibaratkan ikanikan yang bere-nang di lautan lepas. ${ }^{26}$

Berdasarkan pendapat di atas dapat dipahami bahwa semua bendabenda di langit bergerak dan beredar,

${ }^{23}$ Shihab Op.cit. Volume 11, h 540

${ }^{24}$ Wahbah Zuhaili, Tafsìr al-Munir, Jilid 23 Beirut-libanon: Dar al-Fikr al-Ma'ashir,17.

${ }^{25}$ Sadoe'ddin Djambek, Op.cit. h.13.

${ }^{26 K a t a}$ yasbahun menurut Quraish Shihab 2008, jilid 11:543 mempunyai makna pada mulanya berarti mereka berenang. Menurut Shihab ruang angkasa diibaratkan oleh al-Qur an dengan samudera yang besar. Benda-benda langit diibaratkan dengan ikan-ikan yang berenang dilautan lepas. Allah melukiskan benda-benda itu dengan kata yang digunakan bagi yang berakal mereka berenang. Ini mengisyaratkan ketundukan benda-benda langit itu kepada ketentuan dan takdir yang ditetapkan Allah atasnya. tak ter-kecuali matahari. Dalam peredarannya, sangat mustahil terjadi tabrakan, karena telah memiliki keteraturan sistem.

Peredaran matahari dan bulan seperti yang dikemukakan di atas dapat terjadi karena semua benda-benda yang ada di langit telah ditundukkan oleh Allah, sebagaimana dinyatakan dalam QS. Ibrahim (14): 33, Lukman (31): 29, Fāṭir (35): 13, dan Az-Zumar (39):5. Mengacu pada beberapa ayat tersebut, dapat ditarik kesimpulan: 1) konsistensi per-edaran benda-benda langit terjadi karena masing-masing benda-benda langit telah ditentukan tempat edarnya. 2) Konsistensi peredaran benda-benda langit terjadi karena setiap benda langit telah ditentukan waktu ber-edarnya. 3) Konsistensi per-edaran benda langit dapat terjadi karena setiap benda langit telah di-tundukkan oleh Allah.

Selain Ayat-ayat yang telah dijelaskan di atas, ada satu ayat tentang peredaran bulan yang tidak disebutkan secara ber-samaan dengan matahari, itupun menggunakan kata hilāl (هلال) yakni QS. Al-Baqarah [2]: 189. Penulis tidak mengelompokkan ayat ini dalam daftar kelompok ayatayat peredaran bulan dan matahari, karena ayat ini tidak secara implisit berbicara tentang peredaran bulan. Ayat ini secara implisit membicarakan hilāl sebagai tanda-tanda waktu haji, sebagaimana dinyatakan sebagai berikut:

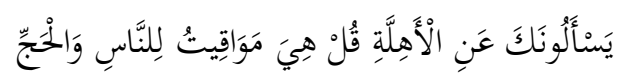

Mereka bertanya kepadamu tentang bulan sabit. Katakanlah: "Bulan sabit itu adalah tanda-tanda waktu bagi manusia 
dan (bagi ibadah) haji (al-Baqarah [2]: 189).

Al-Qurtubi menceritakan bahwa ayat ini diturunkan berkenaan dengan pertanyaan orang-orang Yahudi kepada Muadz bin Jabal mengenai hilāl. Lalu Muadz menyampaikan pertanyaan tersebut kepada Rasulullah kemudian turun ayat ini. Dengan demikian, ayat ini secara substansi tidak berkaitan dengan peredaran bulan, namun ayat ini lebih menekankan pada hikmah adanya perubahan hilāl. Dilihat dari asbab nuzulnya ayat ini mengindikasikan adanya perubahan hilāl. Dalam hal ini, adanya perubahan hilāl dari yang paling halus sampai yang paling jelas. Oleh karena itu, perubahan tersebut mengandung arti dan manfaat bagi manusia. Ibnu Katsir menjelaskan hikmah perubahan hilāl antara lain, untuk mengetahui bilangan iddah wanita, waktu haji, dan waktu memulai serta mengakhir puasa Ramadan. ${ }^{27}$

Secara eksplisit ayat 189 surah alBaqarah mengindikasikan perubahan waktu secara stagnan dalam perhitungan bulan kamariah. Dalam hal ini, perjalanan hilāl dari manzilah ke manzilah akan mengakibatkan perubahan bentuk penampakan hilāl dan implikasi-nya terhadap perubahan waktu. Penampakan bentuk hilāl dalam perjalanan dari manzilah yang satu ke manzilah yang lainnya

${ }^{27 I b n ~ K a s ̦ i ̄ r, ~ T a f s i ̄ r ~ a l-Q u r ' a ̄ n ~ a l-' A z i ̄ i m, ~}$ ditahqiq oleh Samī bin Muhammad Salāmah, Beirut: Dār Tayyibah linasyri wa al-Tauzī'i, 1999 cet II, h.29. mengakibatkan adanya tarikh (penanggalan) kamariah dari tanggal 1, 2, 3, dan seterusnya sampai dengan tanggal 29 atau 30. Setiap tanggal tersebut, hilāl menunjukan bentuk yang berbeda. Perubahan tersebut terjadi secara terus menerus dan stagnan, artinya apabila bulan telah sampai tanggal 29/30 akan kembali lagi menjadi tanggal 1.

\section{F. Penutup}

Kajian mengenai astronomi dalam al-Quran merupakan kajian yang cukup menarik. Secara umum pembicaraan mengenai benda-benda langit dalam perspektif al-Quran terdiri dari matahari, bulan dan bintang. Ketika membicarakan matahari, al-Quran selalu konsisten dengan kata syams dalam bentuk mufrad. Sedangkan, ketika berbicara mengenai bulan, kadang-kadang menggunakan kata qomar dalam bentuk mufrad, kadang pula menggunakan kata hilāl dalam bentuk jamak (ahillah/هاها). Ketika berbicara mengenai bintang digunakan tiga kata, yakni kata nujūm, kaukab dan burūj.

Benda-benda di langit dalam perspektif al-Quran sudah ditetapkan takdirnya, dan telah ditundukkan, sehingga beredar secara konsisten dan pasti. Bulan ditetapkan manzilahmanzilah-nya, sehingga bulan ketika dilihat dari bumi menunjukkan wujud yang berbeda-beda, kadang sempurna (bulan purnama), kadang menunjukkan wujud yang tidak sempurna. Dengan demikian, dapat dikenal dengan baik, kapan bulan tanggal 1, 2, 3 dan seterusnya, sehingga dapat melaksanakan ibadah berdasarkan perjalanan bulan tersebut. [] 


\section{DAFTAR PUSTAKA}

Depag RI, Islam Untuk Disiplin Ilmu Astronomi, Jakarta: Dirjen Bagais, 2002.

Djambek, Saadoe'ddin, Hisab Awal Bulan, Jakarta: Tintamas, 1976.

Humad, As'ad Mahmud, Aysar alTafāsīr:Tafsīr, Asbāb al-Nuzūl, alHadīs Namāzij I'rab, Damaskus: tp, 1992.

Ibn Kas̀īr, Tafsīr al-Qur'ān al-'Azìim, ditahqiq oleh Samī bin Muhammad Salāmah, Dār Țayyibah linasyri wa al-Tauzì'i,tp, 1999/1420 cet II.

Ibn Manżūr, Muhammad bin Mukrim bin Manżur al-Ifriqī al-Mișrī, Lisān al-A'rabi, Beirut-Lebanon: Dār Șādir, tth.

Ichwan, Muhammad Nor, Tafsir 'Ilmi Memahami al-Quran melalui Pendekatan Sains Modern, Jogyakarta, 2004.

Jailani, Zubair Umar, al-Khulāșah alWafiyyah fi al-Falak bi Jadwal alLughāritmiyyah, Kudus: Menara Kudus, t.t

Khazin, Muhyidin, Ilmu Falak, Yogyakarta: Buana Pustaka, 2004

Mahlī dan as-Suyutī, tt. Tafsir alJalālain,tp,tt.

Munawir, AW, Kamus Arab-Indonesia, Surabaya:Pustaka Progresif, 1997

Poedjawijatna, Pembimbing Ke Arah Alam Filsafat, Jakarta: PT Rineka Cipta, 1997.

Quraish Shihab, Tafsir al-Misbah, Vol. 3, 4, 10, 11, 12, 13, 14, Jakarta: Lentera Hati, 2006.

Sa'di, 'Abdu al-Rahman bin Nāśir bin alSa'di, Tafsìr al-Karìm al-Rahman fi
Tafsīr Kalām al-Manān, tahqiq 'Abd al-Rah-man bin ma'lā alWīhaq, Beirut: Muassah al-Risalah, tth.

Tabarī, Muhammad bin Jarīr bin Yazid bin Kaśir bin gālib al-Amlī, Jāmi' alBayān fì Ta'wīl al-Qurān, juz 24, tahqiq Ahmad Muhammad Syākir, Beirut:Muassah ar-Risalah,tt cet I

Wicks, Keith, Stars And Planet, terj. Bambang Hidayat London: Grisewood \& Dempsey Ltd, 1997.

Zamakhzari tt, Tafsir al-Kassyaf, juz 2, tp.

Zuhaili, Tafsìr al-Munīr, Juz 11, 12, 13, 21, 23, Beirut: Dār al-Fikr alMa'așir, 1991. 